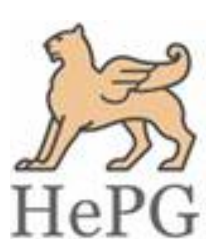

ISSN: 2348-1900

Plant Science Today

http://www.plantsciencetoday.online

open 6 ACcess

Mini Review

\title{
Drought stress in plants: An overview on implications, tolerance mechanisms and agronomic mitigation strategies
}

\author{
Sadam Hussain $^{1^{*}}$, Saddam Hussain ${ }^{1}$, Tauqeer Qadir ${ }^{1}$, Abdul Khaliq ${ }^{1}$, Umair Ashraf ${ }^{2}$, Abida Parveen ${ }^{3^{* *}}$, \\ Muhammad Saqib ${ }^{4}$ \& Muhammad Rafiq $^{4}$
}

${ }^{1}$ Department of Agronomy, University of Agriculture, Faisalabad 38040, Pakistan

${ }^{2}$ Department of Botany, University of Education, Faisalabad-campus, Pakistan

${ }^{3}$ Department of Botany, Government College University Faisalabad, Pakistan

${ }^{4}$ Agronomic Research Institute, Ayub Agricultural Research Institute, Faisalabad, Pakistan

\section{Article history}

Received: 26 May 2019

Accepted: 05 August 2019

Published: 01 October 2019

\section{Publisher}

Horizon e-Publishing Group

\section{Correspondence \\ "Sadam Hussain \\ 空.sadam423@gmail.com \\ ${ }^{* *}$ Abida Parveen

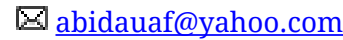

\begin{abstract}
Drought is considered as one of the major limiting factors affecting growth and productivity of crop plants. It severely affects the morphological and physiological activities of the plants and hampers the seed germination, root proliferation, biomass accumulation and final yield of field crops. Drought stress disrupts the biosynthesis of chlorophyll contents, carotene and decreases photosynthesis in plants. It gradually reduces $\mathrm{CO}_{2}$ assimilation rates owing to decrease in stomatal conductance. In addition, drought affects cell membrane stability and disrupts water relations of a plant by reducing water use efficiency. To cope with these situations, plants adopt different mechanisms such as drought tolerance, avoidance and escape. In this review, we discussed about the effects of drought on morphological and physiological characteristics of plants and suggested the different agronomic practices to overcome the deleterious effects of drought stress.
\end{abstract}

Keywords: Antioxidants; Drought; Seed germination; Photosynthesis; Crop yield

Citation: Hussain S, Hussain S, Qadir T, Khaliq A, Ashraf U, Parveen A, Saqib M, Rafiq M. Drought
stress in plants: An overview on implications, tolerance mechanisms and agronomic
mitigation $\quad$ strategies. https://doi.org/10.14719/pst.2019.6.4.578

Copyright: (c) Hussain et al (2019). This is an open-access article distributed under the terms of the Creative Commons Attribution License, which permits unrestricted use, distribution, and reproduction in any medium, provided the original author and source are credited (https://creativecommons.org/licenses/by/4.0/).

Indexing: Plant Science Today is covered by Scopus, Web of Science, BIOSIS Previews, ESCI, CAS, AGRIS, CABI, Google Scholar, etc. Full list at http://www.plantsciencetoday.online

\section{Introduction}

Different abiotic stresses such as high and low temperature, drought, heavy metals and soil salinity are detrimental to the growth, development and productivity of field crops (1). Drought stress is mainly caused by no or low rainfall in dry or wet season and/or deviation of rainfall pattern from its normal period (2). Alarmingly, $10 \%$ of the total land will suffer drought stress during early of $21^{\text {st }}$ century that can be increased up to $40 \%$ by the end of this century (3).

Imposition of drought caused morphophysiological, anatomical and molecular changes in plants. Water stress conditions severely affect 
the morphology of crops by inhibiting seed germination, and early growth of plants $(4,5)$. The drought stress reduces the plant biomass accumulation and partitioning, harvest index and productivity of crops (6). Approximately $70 \%$ yield in various crops was reduced by drought stress $(7,8)$.

Different physiological activities in plants such as osmotic adjustment, water relations, photosynthesis and respiration are disturbed under drought stress $(9,10)$. The mechanism of yield reduction under water stress condition is linked to the reduced light absorption, low photosynthetic rates, water use efficiency (WUE) and harvest index (11).

The level of vulnerability of crop against drought stress depends on its severity, plant genotypes and stage of crop growth (12). Plant survive under limited water supply through several morpho-physiological and biochemical mechanism eg., by changing their architecture, controlling growth rate, adjusting water balance of the cells and tissues and activating the antioxidative defense systems (13). This review discusses the effects of drought on morphological and physiological activities of plants and describes the mechanism adopted by the plants to adapt/survive under drought conditions. It also highlights the different agronomic approaches for reducing the effects of drought stress on crop plants under field conditions.

\section{Effect of drought on plant morphology}

\section{Seed germination}

Seed requires the proper amount of water for germination, however under water deficit conditions, it is unable to imbibe and germinate even all other external/internal conditions are favorable. Hence, reduced seed germination and poor stand establishment are the primary signs of drought at early crop growth stages (4). Drought stress substantially reduced the germination and stand establishment in various field crops $(14,15)$.

Many legumes, cereals, and fodder species have shown poor seed germination under drought stress. For instance, poor seed germination and stand establishment were recorded under water deficit conditions in rice and peas (16-18). Moreover, poor germination in Alfalfa (Medicago sativa) was also recorded under drought stress conditions (19). It seems to be clear that water deficit causes poor germination and reduced stand establishment in various field crops. Therefore, adequate moisture supply is an absolute requirement for early growth of various crops.

\section{Root growth}

A well develop root system helps the plants to anchor as well as uptake of water and nutrients from its immediate vicinity to which it exists. Drought causes apparent modifications in the root architecture and morphological characters in crop plants. Most often, the root growth under mild drought conditions is not severely affected. For example, the root growth in maize was not substantially affected under water deficit conditions (20). However, the root growth under deficit water conditions was increased in Catharanthus roseus (21) and Helianthus annuus (22). On the other hand, a significant decrease in the dry weight of roots in Populus (23) and some species of sugar beet (24) were recorded under severe drought stress. In general, drought stress increased the root-shoot ratio in different plant species (25).

\section{Leaf area}

Drought stress causes significant reduction in leaf area of many plant species. The increase in leaf area mainly depends on the leaf turgor pressure, canopy temperature and availability of photoassimilates $(26,27)$. Leaf area growth is the main factor for photosynthesis and grain yield (28). Water deficit conditions reduced the leaf area by reducing leaf expansion and thus affect the process of photosynthesis (27). Furthermore, the leaf area of maize (29), rice (30), wheat (31), soybean (32) and many other field crops (14) was significantly affected under limited water conditions.

\section{Leaf rolling}

Leaf rolling is the loss of the potential pressure due to water loss from the upper epidermis of leaf; the phenomenon helps to reduce leaf temperature, interception of incident radiation and transpiration rate $(33,34)$. Drought stress increased the leaf rolling in different plant species. Drought stress decreased the cell size, stomatal activity, leaf area and increased the leaf rolling (30). A study of two rice cultivars 'IRAT109' (drought tolerant) and 'Zhenshan97B' (drought sensitive) showed that drought stress significantly limitted plant height, increased the leaf rolling and reduced the final yield of susceptible cultivar under drought stress (30). Furthermore, studies reported that some agronomic traits for drought response are increased leaf rolling, decreased rootshoot length, relative water contents (RWC), panicle length, grains per panicle and dry biomass accumulation (18).

\section{Plant height}

The internal plant factors involved to enhance the plant height are substantially affected by drought stress. A decline in plant height could be attributed to the reduction in cell expansion, increase in leaf abscission under drought conditions (5) and impaired mitosis (35). The plant height is largely associated with cell enlargement and leaf senescence. Generally, lower cell enlargement and higher leaf senescence are the basis of reduction in 
plant height. Several studies have been reported that the plant height in different field crops such as wheat (36), maize $(29,37)$, peas (38), and soybean (39) was decreased under drought stress. Furthermore, drought stress also reduced the height in some fruit plants, for example there are reports on $25 \%$ reduction in height of citrus plants grown under water deficit conditions (40). Similarly, plant height of Abelmoschus esculentus decreases with more leaf senescence and less cell enlargement under drought stress (41). A systematic approach should be adopted by conventional breeding instead of traditional breeding to improve plant height of crops being cultivated in drought prone areas.

\section{Mechanism of growth reduction}

Growth of plant can be accomplished by cell division, cell enlargement and other physiological, ecological as well as morphological events. Plant growth is highly dependent on these events. Drought stress can severely impair these activities. Mechanism of growth reduction under drought stress as; (a) reduced cell turgor pressure, b) abridged water uptake and c) reduced photosynthesis and photo-assimilates required for cell division, mitosis and cell enlargement which often lead to reduction in plant height $(14,35)$. The phenomenal changes in plant growth under drought stress are presented in (Fig. 1). In a study, it has been described that cellular growth is quite sensitive to drought and is severely inhibited by interruption of water flow from xylem to the surrounding cells (142). Abating mitosis, impaired cell elongation and expansion under drought stress are the major factors which reduce the plant height, leaf area and crop growth (15).

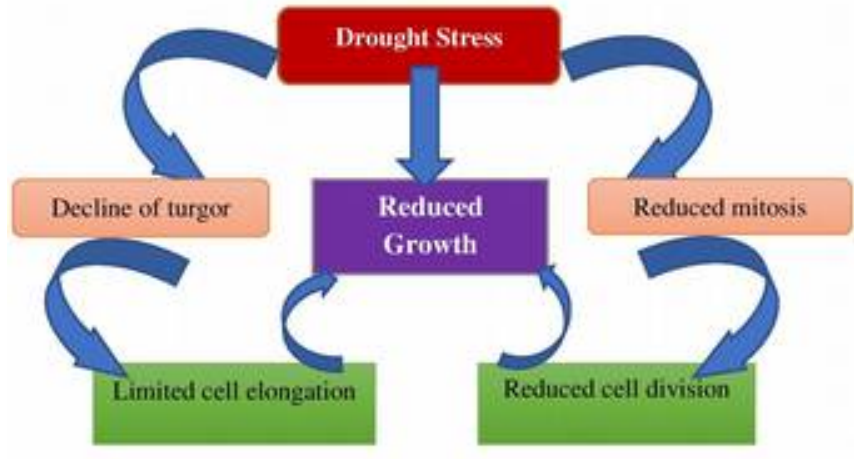

Fig. 1. A schematic representation of plant growth reduction mechanism under water deficit conditions

\section{Plant biomass and yield}

Drought stress causes significant reduction in dry biomass accumulation and grain yield in different filed crops (42). Similarly, imposition of drought stress at silking, grain-filling and maturity stages led to reduce the total dry biomass by $37 \%, 34 \%$ and $21 \%$ respectively in maize crop (43). Drought stress generally caused grain yield reduction in all agronomic crops. The yield reduction due to drought stress in different field crops has been listed in (Table 1). The grain yield reduction mainly depends upon the time of the onset of drought and stage of the crop. Similarly, drought

Table 1. Yield reduction (\%) in different crops under drought stress

\begin{tabular}{lrl} 
Crop & $\begin{array}{c}\text { Yield } \\
\text { reduction } \\
\text { (\%) }\end{array}$ & References \\
\hline Wheat & 64.46 & Rizza et al. (55) \\
\hline Barley & 50 & Samarah et al. (56) \\
\hline Maize & $63-87$ & Kamara et al. (43) \\
\hline Rice & $53-92$ & Lafitte et al. (57) \\
\hline Canola & 30 & Sinaki et al. (58) \\
\hline Soybean & $46-71$ & Samarah et al. (59) \\
\hline Pigeon pea & $40-55$ & Nam et al. (60) \\
\hline Cowpea & $55-65$ & Ogbonnaya et al. (61) \\
\hline Chickpea & $45-69$ & Nayyar et al. (45) \\
\hline Sunflower & 60 & Mazahery-Laghab et al. (62) \\
\hline
\end{tabular}

stress at flowering and grain filling stages reduced the grain yield in maize (44), green gram and common beans (45), parsley (46) and wheat (47, 48). In addition, drought stress at pre-anthesis stage reduced the grain size and number of grains in wheat (49) whilst after anthesis, it reduced the grain filling period in different cereal crops (50). Furthermore, drought stress at silking stage caused phenological delay between silking and anthesis stages, and reduced the total number of grains and grain yield in maize $(43,51)$. Drought stress at heading and maturity stages reduced the total dry biomass and grain filling percentage in wheat (52). The enzymes, i.e., starch synthase (SS), adenosine diphosphate glucose pyrophosphorylase (ADGP), starch branching enzyme (SBE) and sucrose synthase (SS) are involved in the grain filling process of cereals (53) and severely affected by drought stress (54, Table 1).

\section{Effect of drought on plant physiology Chlorophyll contents}

Chlorophyll is the main component of chloroplast which plays a significant role in the photosynthesis. Chlorophyll pigments are essential for the plants to capture light and utilize in the functioning of photosynthesis (9). Under water deficit conditions, the chlorophyll contents have considerably reduced due to enhanced oxidative stress and/or deterioration or photo-oxidation of the chlorophyll pigments. Drought stress considerably reduced the functioning of both chlorophyll $\mathrm{a}$ and $\mathrm{b}(14,37)$. In a study it has also been identified that the reduction of chlorophyll a, $\mathrm{b}$ and total chlorophyll contents of sunflower under drought conditions (63). Likewise, the chlorophyll contents were sharply reduced i.e., $29 \%$ and $42 \%$ in Chemlali and Chétoui olive cultivars, respectively under drought stress (64). The chlorophyll contents were reduced in response to the water deficit conditions in mesophyll cells of the leaf and a small amount are 
also decreased through bundle sheath cells (65). In fact, the drought conditions severely affect the biosynthesis and functioning of the chlorophylls in plants that could have severe consequences on photosynthetic machinery and assimilate partitioning. Different metabolic processes and activities are disturbed by drought stress which in turn lead to reduction in chlorophyll contents. This reduction can also be attributed to the inhibition of biosynthesis of precursors of chlorophyll under drought stress (143). Drought stress may also cause severe reduction of sodium and potassium contents of root and shoot (143). Owing to stomatal closure under drought stress, absorption of $\mathrm{CO}_{2}$ is limited which may promote the imbalance between the electron requirement of CalvinBenson cycle and photochemical activity of photosystem II and result into photo-inhibitory damage to reaction centers of PSII (144).

\section{Carotenoids}

Several studies have reported a decrease in carotenoids contents in various crops under drought stress $(63,145-148)$. Carotenoids are grouped into hydro-carbon carotenes, consisted on lycopene and xanthophylls or $\beta$-carotene and they are characterized by lutein (66). They play a major role in anti-oxidant protection system but highly susceptible to the over-activation of reactive oxygen species (ROS) (28). The enzymatic antioxidant system together with non- enzymatic system i.e., $\beta$ - carotenes, $\alpha$-tocopherol, ascorbate, reduced glutathione and enzymes containing ascorbate peroxidase, peroxidase, polyphenol oxidase, catalase and glutathione reductase provide protection to carotenoids against ROS (67). $\beta$-carotene directly involved in the reduction of triple chlorophyll which inhibits the generation of the singlet oxygen and thus protects from oxidative damage (14). Additionally, $\beta$-carotene plays a main role in protecting and sustaining photochemical processes as well (68).

\section{Photosynthesis}

Drought stress hampered the photosynthetic system by altering $\mathrm{CO}_{2}$ conductance through stomata, carbon cycle, electron transport chain (ETC) of thylakoid membrane, membrane lipid peroxidation and water imbalance $(1,69)$. Under water deficit conditions, limited gaseous exchange causes a reduction in leaf growth, premature leaf abscission, oxidation of protein and limited photosynthesis (70). According to a study, drought in maize led to significant reductions in net photosynthesis, transpiration, stomatal conductance, inter-cellular $\mathrm{CO}_{2}$, water use efficiency, and intrinsic water use efficiency as compared with the well-watered crop (37). The mechanism of photosynthesis reduction in plants under drought stress is as: i) reduction in chlorophyll biosynthesis, ii) stomatal closure through ABA signaling which reduce carboxylation process, iii) reactions of ROS with the cellular lipids and proteins, and iv) reduced RuBP and PEP-case activity (14). Hence, drought caused reduction in photosynthesis is an intricate phenomenon that is affected by various intrinsic and extrinsic factors.

\section{Respiration}

Drought often causes reduction in the rate of respiration in different plant parts such as leaves (71), shoots (72), roots (73), flower apices (74) and in whole plant as well (75-77). Several researchers described the unaffected $(78)$, or increase $(79,80)$ rate of respiration in plants under the limited water supply. However, all kinds of respiration were stopped at low water potential ( -35 bars) (10). The soil selection under limited water supply is important for respiration of many plant species. Similarly, according to Collier and Cummins (81) rate of respiration in leaves is also slow when plants are grown on high organic soils, as compared to the vermiculite soil, in which drought conditions develop very rapidly.

\section{Stomatal conductance}

Responses of stomatal conductance are more likely to be associated with the soil moisture than leaf moisture contents. However, gaseous exchange through stomata is not only affected by the soil water content but also other external and internal plant factors (14). Severity in drought stress causes intensively caused stomatal closure and thus reduces net photosynthesis. A study conducted on Chinese Hibiscus revealed that under limited soil water contents, the rate of transpiration, stomatal conductance, water-use efficiency and RWC were decreased (82).

\section{Cell Membrane Stability (CMS)}

The cell membrane stability (CMS) can be used as an index of selecting drought tolerant genotypes (17). CMS and cell membrane integrity under water deficit conditions propose resistance against water stress. Genotypes having lower the CMS values showed higher vulnerability to drought stress and vice versa (83). Similarly, CMS index is substantially important in breeding programmes and predicts drought tolerance or sensitivity criteria (84). The genotypes with $<50 \%$ value for CMS are more vulnerable to drought, whereas genotypes having CMS values ranged $71-80 \%$ showed more potential towards drought tolerance (83). Under limited water supply, CMS showed positive association with tillering ability and grain yield of wheat, but negative with 1000-grain weight (85). Furthermore, drought activates the oxidative process in plant species which finally reduces the membrane stability owing to lipid peroxidation (70), and consequently damages the cell membrane (86).

\section{Water use efficiency}

The proportion between dry-matter produced and the amount of water consumed is known as water 
Table 2. Effect of soil water contents on relative water contents, transpiration, and photosynthesis in different plants

\begin{tabular}{|c|c|c|c|c|c|}
\hline Crop & $\begin{array}{l}\text { Soil water } \\
\text { content }\end{array}$ & RWC (\%) & 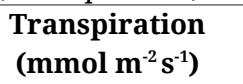 & $\begin{array}{l}\text { Photosynthesis } \\
\left(\mathrm{molm}^{-2} \mathbf{s}^{-1}\right)\end{array}$ & References \\
\hline \multirow[t]{2}{*}{ Winter wheat } & Well-watered & $79.4 \pm 1.93$ & $6.0 \pm 0.58$ & $9.7 \pm 0.02$ & Roohi et al. (92) \\
\hline & Water deficit & $70.1 \pm 3.25$ & $3.51 \pm 0.44$ & $5.1 \pm 1.19$ & \\
\hline \multirow[t]{3}{*}{ Soybean } & $100 \%$ & - & 11.6 & 17.45 & Purwanto (93) \\
\hline & $50 \%$ & - & 5.5 & 8.67 & \\
\hline & $25 \%$ & & 0.7 & 1.81 & \\
\hline \multirow[t]{2}{*}{ Winter barley } & Well-watered & $77.4 \pm 5.03$ & $4.9 \pm 0.91$ & $7.9 \pm 2.47$ & Roohi et al. (92) \\
\hline & Water deficit & $59.8 \pm 5.09$ & $2.8 \pm 0.41$ & $3.6 \pm 92$ & \\
\hline \multirow[t]{2}{*}{ Spring triticale } & Well-watered & $83.5 \pm 5.02$ & $53 \pm 0.26$ & $8.8 \pm 0.64$ & Roohi et al. (92) \\
\hline & Water deficit & $71.3 \pm 1.37$ & $3.19 \pm 0.38$ & $5.3 \pm 0.70$ & \\
\hline
\end{tabular}

RWC: relative water contents

use efficiency (WUE) of that plant (87). Plant water status is the measure of relative water content (RWC) and the RWC mostly depends on the water uplifting by the plant roots and transpiration rate by the plant leaves and temperature. Furthermore, water deficit conditions considerably reduce the water potential of leaf, transpiration rate and RWC with increasing temperature in plants (88). Moreover, leaves respond quickly to drought and by lowering the water potential and RWC rapidly. Similarly, the leaves of plants which are exposed to the water deficit condition, shown more decline in the RWC and water potential (89). Under limited water condition, the total water content of Barbary fig decreased by $57 \%$ (90). Wheat WUE was higher under drought stress than well-watered conditions (91, Table 2).

\section{Drought mitigation mechanisms}

\section{Morphological approaches}

The most common morphological approaches of plants for drought resistance are; drought tolerance, drought avoidance and drought escape (Fig. 2) $(94$, 95). The drought tolerant plants continue to function normally by maintaining turgor even at low water potential (96). Osmoregulation, osmoprotectants synthesis, osmolyte accumulation and antioxidant activities are the responses of plants against drought stress $(96,97)$. The capability of a plant to complete its life cycle earlier than drought period is termed as drought escape (98). This involves early germination, faster plant growth, flowering and maturity.

The drought avoidance mechanism allows plants to evade dehydration by maintaining internal water status of plants $(94,99,100)$. Decrease in leaf number and size, leaf rolling, and leaf orientation can reduce the water losses and radiation absorption in plants (101-103). Moreover, by improving leaf waxiness, deep and high rooting density often increases water uptake deep from the soils (104-106).

\section{Biochemical mechanisms}

\section{Proline activity}

Turgor pressure of the cell is maintained by the concentration of different solutes, which lesser the osmotic potential of cytosol (107). Proline often determines the association and conservation of the protein structure, hold the membrane's structure under water deficit condition and inhibit the photo-inhibition (108). It also helps to maintain the sub-cellular structures, cleansing of free radicals, mitigating the oxidation-reduction potential (109)

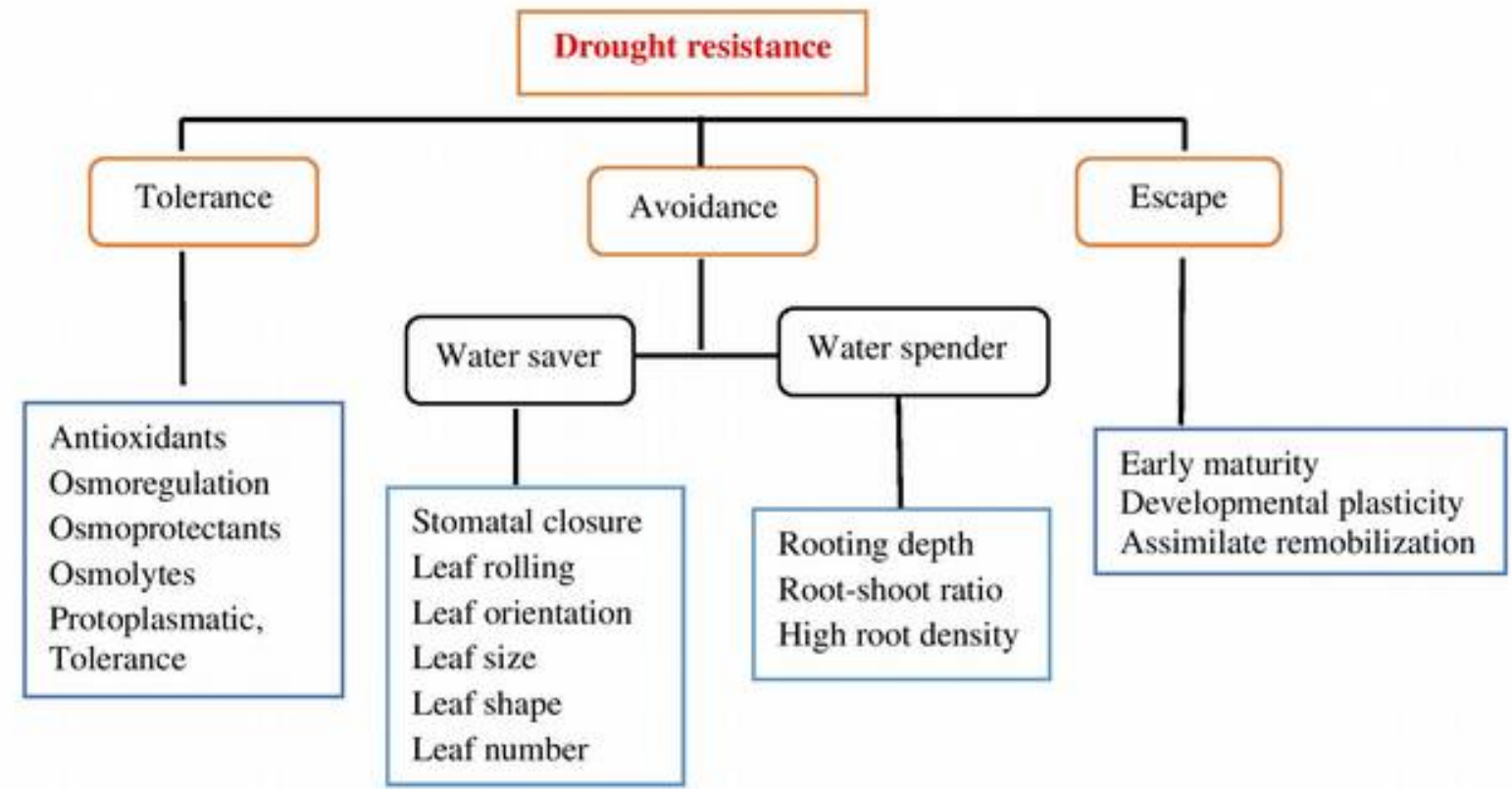

Fig. 2. Morphological mechanisms of a plant under drought condition 


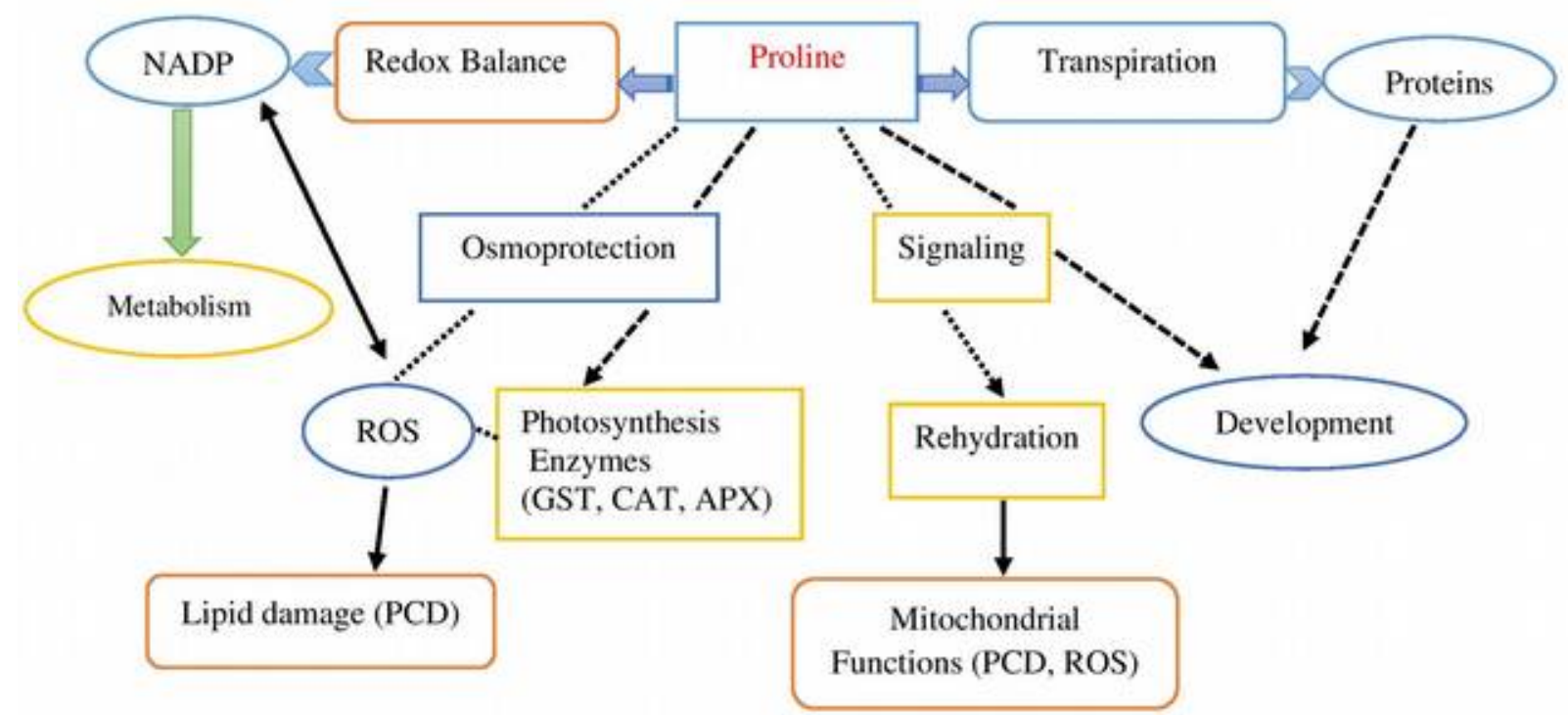

Fig. 3. Functions of proline in plants (adopted from Szabo and Savoure (110) with modifications)

and regulate mitochondrial purposes through the act as signaling molecular substance under drought stress. Additionally, it also determines the cell development and cell death and activates the particular gene aspects which are necessary for retrieval of the plant from drought stress (110).

The mechanism of proline under drought is depicted in (Fig. 3). Under limited water condition, the maintenance of cell turgor pressure can be attained by the regulation of osmotic potential by synthesizing proline, carbohydrate, sucrose, glycine-betaine, and other solutesubstances in the cytoplasm. Increased proline contents were directly associated with drought tolerance in wheat (111). Similarly, in maize, the proline percentage increases as the water deficit condition prolonged and reached to its peak 10 days after imposition of drought, but reduced under the acute water stress (37).

\section{Molecular mechanisms}

Low availability of water in soil may lead to cellular water deficit in plants. Up- and downregulation of gene expression can take place under these conditions. In response to water deficit conditions, the activity of a number of genes is triggered which enhances the plants' tolerance to drought stress (149). Gene expression may also be triggered as a result of injury and/or triggered directly as a result of other biotic and abiotic stresses. It is also well documented that plants' ability to tolerate drought is a multiplex phenomenon and is an outcome of expression of multiple genes.

\section{Aquaporins}

Aquaporins (AQs) have the ability to facilitate the protein mediated membrane transport in plants (14). Although, different studies demonstrated the understanding of AQs and plant water relation in plants (150), however relation between AQs and crop resistance to drought stress has not been fully illustrated. Maurel and Chrispeels (150) reported that under water deficit conditions, AQs can increase the water permeability by regulating the hydraulic conductivity of membranes.

In a recent year, different researchers carried studies on plant water relations and AQs in plants. Different reports clearly indicate that AQs play important role in uptake of water through plants roots by declining root hydraulic conductivity (151), and play a major role in cellular osmoregulation (152). More expression of plasma membrane AQs in tobacco was reported which improved the plant vigor of tobacco however, overexpression of prolactin-inducible protein $1 \mathrm{~b}$ gene caused fast wilting under drought stress $(152,153)$. Different reports demonstrated the specific functions and regulation of intrinsic AQs of plasma membrane. For instance, their overexpression in roots have been reported which can mediate the soil water uptake by roots, and down-regulation of prolactin-inducible protein in trans genetic plants have lower water uptake capacity of plants $(151,152)$.

\section{Stress proteins}

To cope with drought stress, the synthesis of different proteins has been reported. Among these proteins, mostly are water soluble and thus enhance the stress tolerance by hydration of cellular structure (154). A variety of stress proteins are implicated under drought which enhance the tolerance capability of plants (53). The induction of dehydration-responsive element-binding genes (DHG) (dehydration-responsive element-binding gene1 and dehydration-responsive elementbinding gene2) under dehydration (155). These genes are involved in signal pathways under stressed conditions. The manipulation of these genes in plants may enhance the drought tolerance ability of these plants (156). Previous studies have reported drought tolerance in rice and groundnut by manipulation of DHG $(157,158)$. Apart from 
DHG, different capsella bursa-pastoris like genes are also synthesized under drought stress (159). Introduction of DHG in transgenic tall fescue may result in more accumulation of proline which increases the drought resistance in crops. This phenomenon indicates the ability of capsella bursa-pastoris 3 to induce tolerance against drought (160). The expression of some dehydrins and late embryogenesis abundant genes have also been reported under drought stress (161). Lowmolecular-weight heat shock proteins also play a role in increasing the capability of plants to cope with abiotic stresses (154, 162). Different membrane-stabilizing proteins are another group of protein which is responsible for enhancing the drought tolerance in various crops. These increase the water-binding capacity by creating a protective environment and also play an important role in the sequestration of ions (163).

\section{Different Agronomic Practices to overcome the drought effects}

\section{Changing the sowing time}

Planting date is an important factor regarding drought escape in subtropical, tropical and rained conditions (112). Early planting under dry conditions is corrected by improving WUE, changing the sowing time so that plant does not suffer drought stress specially at critical stages (100). The cropping system that provides balance and adequate water with an appropriate quantity of nutrients will improve canopy growth and yield by enhancement of biomass production. The more of canopy area, the more will be the evapotranspiration (113). Consequently, changes in the production of biomass through each unit of transpiration by adjusting planting dates can be a helpful strategy for drought tolerance or drought escape (114).

\section{Adequate supply of Irrigation and Soil amendments}

Topsoil modifications affect soil water by infiltration, evaporation and environment-soil heat transfer (115). Water can be preserved in soil by different means and mulching is one of them which can substantially reduce the evaporative losses while could enhance the uptake and storage of water in plant root zone $(115,116)$.

The current irrigation systems, likewise, drip, film hole and sprinkler irrigation are more efficient and water saving techniques that improve WUE and grain yield as compared to the surface irrigation $(115,117)$. Therefore, modern irrigation techniques are more suitable for supplying adequate irrigation needed for plant growth and development. The modern irrigation systems are more suitable for cash crops, through delivering the proper amount of water for plant growth under sloppy areas (118). Furthermore, crop yield can be enhanced up to $70 \%$ by providing supplemental irrigation and soil management practice at the reproductive growth stage (115).

\section{Seed priming}

Seed priming is the most pragmatic and short-term strategy to reduce the effects of drought stress in crop plants $(14,147,164,165$; Table 3). A partial hydration of seed towards a point associated with a start of metabolic processes of germination but no radicle emergence occur is known as seed priming (119). Better and uniform germination

Table 3. Various seed priming techniques adopted for developing drought tolerance in plants

\begin{tabular}{|c|c|c|}
\hline Plants & Priming method & Authors \\
\hline Wheat & $\begin{array}{l}\text { Hydropriming, auxin } \\
\text { priming, halopriming } \\
\left(\mathrm{CaSO}_{4}\right) \text {, chemical } \\
\text { priming }\left(\mathrm{KH}_{2} \mathrm{PO}_{4}, \mathrm{H}_{2} \mathrm{O}_{2} \text {, }\right. \\
\text { SNP), gibberellic acid } \\
\left(\mathrm{GA}_{3}\right) \text { priming }\end{array}$ & $\begin{array}{l}\text { Das and } \\
\text { Choudhury (122); } \\
\text { Ghana and } \\
\text { Schillinger (123); } \\
\text { Akbari et al. (124); } \\
\text { Wahid et al. (125) }\end{array}$ \\
\hline Rice & $\begin{array}{l}\text { Hydropriming, PEG, } \\
\mathrm{KCl}, \mathrm{CaCl}_{2} \text {, ascorbate, } \\
\text { priming }\end{array}$ & $\begin{array}{l}\text { Basra et al. (126); } \\
\text { Farooq et al. (127); } \\
\text { Yari and Sheidaie } \\
\text { (128); Yuan-Yuan } \\
\text { et al. (129) }\end{array}$ \\
\hline Maize & $\begin{array}{l}\text { Chemical priming } \\
\left(\mathrm{CuSO}_{4} \text {, } \mathrm{ZnSO}_{4}\right) \text {, on- } \\
\text { farm seed priming }\end{array}$ & $\begin{array}{l}\text { Murungu et al. } \\
\text { (130); Finch-Savage } \\
\text { et al. (131); Foti et } \\
\text { al. (132); } \\
\text { Janmohammadi et } \\
\text { al. (133) }\end{array}$ \\
\hline Sugarcane & Halopriming $(\mathrm{NaCl})$ & Patade et al. (134) \\
\hline Cotton & $\begin{array}{l}\text { Hydropriming, } \\
\text { hormonal (GA3) }\end{array}$ & $\begin{array}{l}\text { Murungu et al. } \\
\text { (130); Casenave } \\
\text { and Toselli (135); } \\
\text { Akbari et al. (124) }\end{array}$ \\
\hline Chickpea & $\begin{array}{l}\text { Hydropriming, } \\
\text { osmopriming } \\
\text { (mannitol) }\end{array}$ & $\begin{array}{l}\text { Kaur et al. }(136, \\
\text { 137); Elkoca et al. } \\
\text { (138) }\end{array}$ \\
\hline Sunflower & $\begin{array}{l}\text { Hydropriming, } \\
\text { osmopriming }\left(\mathrm{KNO}_{3}\right)\end{array}$ & Kaya et al. (15) \\
\hline Mustard & $\begin{array}{l}\text { Hydropriming, } \mathrm{NaCl} \\
\text { priming, } \mathrm{ABA} \text { priming }\end{array}$ & $\begin{array}{l}\text { Srivastava et al. } \\
(139,140)\end{array}$ \\
\hline Canola & Hydropriming & Omidi et al. (141) \\
\hline
\end{tabular}

was found in primed seeds (15). Osmopriming with saturated $\mathrm{CaHPO}_{4}$ and $\mathrm{KCl}(4 \%)$ solution resulted in improved germination, better stand establishment and yield of direct seeded rice under water stress conditions (120). Similarly, primed seed of rice showed better germination, rapid seedling establishment and uniform crop architecture that led to the improved yield (4). Under water deficit conditions, primed wheat seeds showed $44 \%$ more germination than unprimed seeds (121).

\section{Conclusions}

Drought stress often resulted in substantial loss in growth and yield agronomic crops. Drought stress impedes various morphological and physiological processes in different crops. It generally reduces seed germination and impairs stand establishment, reduces leaf area, overall plant growth and total dry biomass accumulation in different crops. Drought stress hampers the 
photosynthetic and gas exchange attributes chlorophyll biosynthesis and cell membrane integrity as well as alterations in phonological development of crops. Plants respond to water deficit conditions by drought avoidance and tolerance mechanism eg., by changing their leaf shape, leaf number and size, leaf rolling and leaf orientation which helps to reduce water losses and light interception in plants. Osmoregulation, osmoprotectants biosynthesis, accumulation of compatible solutes and antioxidant activities are the physio-biochemical responses of plants to drought stress. Different agronomic practices such as changing the sowing times, efficient use of irrigation water and seed priming techniques can be quite helpful to minimize the effect of drought stress under field conditions.

\section{Authors' contributions}

All authors contributed to the content of the manuscript and approved the final version.

\section{Competing Interests}

The authors declare that they have no competing interests.

\section{References}

1. Hussain HA, Hussain S, Khaliq A, Ashraf U, Anjum SA, Men S and Wang L. Chilling and drought stresses in crop plants: implications, cross talk, and potential management opportunities. Front. Plant Sci. 2018; 9:393. https://doi.org/10.3389/fpls.2018.00393

2. Alghabari F, Ihsan MZ, Khaliq A, Hussain S., Daur I, Nasim W. Gibberellin-sensitive Rht alleles confer tolerance to heat and drought stresses in wheat at booting stage. J. Cereal Sci. 2016; 70:72-78. https://doi.org/10.1016/j.jcs.2016.05.016

3. Burke EJ, Brown SJ, Christidis N. Modeling the recent evolution of global drought and projections for the twenty-first century with the Hadley Centre climate model. J Hydrometeorol. 2006;7(5):1113-25. https://doi.org/10.1175/JHM544.1

4. Harris D, Tripathi RS, Joshi A. On-farm seed priming to improve crop establishment and yield in dry directseeded rice. In: Pandey S, Mortimer M, Wade L, Tuong TP, Lopes K, Hardy B editors. Direct seeding: Research Strategies and Opportunities, International Research Institute, Manila, Philippines: 2002. p. 231-40.

5. Manivannan P, Jaleel CA, Kishorekumar A, Sankar B, Somasundaram R, Sridharan R, Panneerselvam R. Changes in antioxidant metabolism of Vigna unguiculata L. Walp. by propiconazole under water deficit stress. Colloids Surf B: Biointerf. 2007;57:69-74. https://doi.org/10.1016/j.colsurfb.2007.01.004

6. Challinor AJ, Wheeler TR, Slingo JM, Craufurd PQ, Grimes DIF. Design and optimisation of a large-area process-based model for annual crops. Agr. Forest Meteorol. 2004;124:99-120. https://doi.org/10.1016/j.agrformet.2004.01.002

7. Akram, HM, Ali A, Sattar A, Rehman HSU, Bibi A. Impact of water deficit stress on various physiological and agronomic traits of three basmati rice (Oryza sativa L.) cultivars. J Anim Plant Sci. 2013;23(5):1415-23. Available in: http://www.thejaps.org.pk/.../30.pdf

8. Kaur V, Behl RK, Shinano T, Osaki M. Interacting effects of high temperature and drought stresses in wheat genotypes under semiarid tropics-an appraisal. Tropics. 2008;17:230-38. https://doi.org/10.3759/tropics.17.225

9. Praba ML, Cairns JE, Babu RC, Lafitte HR. Identification of physiological traits underlying cultivar differences in drought tolerance in rice and wheat. J Agron Crop Sci. 2009;195:30-46 https://doi.org/10.1111/j.1439-037X.2008.00341.X

10. Anjum SA, Tanveer M, Ashraf U, Hussain S, Shahzad B, Khan I, Wang L. Effect of progressive drought stress on growth, leaf gas exchange, and antioxidant production in two maize cultivars. Environ. Sci. Pollut. Res. 2016; 23:17132-14. https://doi.org/10.1007/s11356-016-6894-8

11. Earl H, Davis RF. Effect of drought stress on leaf and whole canopy radiation use efficiency and yield of maize. Agron J. 2003;95:688-96. https://doi.org/10.2134/agronj2003.6880

12. Saud S, Chen Y, Fahad S, Hussain S, Li N, Li X, Alhussien SAFE. Silicate application increases the photosynthesis and its associated metabolic activities in Kentucky bluegrass under drought stress and postdrought recovery. Environ. Sci. Pollut. Res. 2016; 23: 17647-55. https://doi.org/10.1007/s11356-016-6957-x

13. Duan B, Yang Y, Lu Y, Korpelainen H, Berninger F, Li C, et al. Interactions between drought stress, $\mathrm{ABA}$ and genotypes in Picea asperata. J Exp Bot. 2007;58:3025-36. https://doi.org/10.1093/jxb/erm160

14. Farooq M, Wahid A, Kobayashi N, Fujita D, Basra SMA. Plant drought stress: effects, mechanisms and management. Agron Sustain Dev. 2009;29:185-212. https://doi.org/10.1007/978-90-481-2666-8 12

15. Kaya MD, Okcu G, Atak M, Cikili Y, Kolsarici O. Seed treatments to overcome salt and drought stress during germination in sunflower (Helianthus annuus L.). Eur J Agron. 2006;24:291-95 https://doi.org/10.1016/j.eja.2005.08.001

16. Okcu G, Kaya MD, Atak M. Effects of salt and drought stresses on germination and seedling growth of pea (Pisum sativum L.). Turk J Agr For. 2005;29:237-42.

17. Tripathy JN, Zhang J, Robin S, Nguyen TT, Nguyen HT. QTLs for cell-membrane stability mapped in rice (Oryza sativa L.) under drought stress. Theor Appl Genet. https://doi.org/10.1007/s001220051424 2000;100:1197-1202.

18. Manickavelu A, Nadarajan N, Ganesh SK, Gnanamalar RP, Chandra BR. Drought tolerance in rice: morphological and molecular genetic consideration. Plant Growth Regul. 2006;50:121-38. https://doi.org/10.1007/s10725-006-9109-3

19. Zeid IM, Shedeed ZA. Response of alfalfa to putrescine treatment under drought stress. Biol Plant. 2006;50:63540. https://doi.org/10.1007/s10535-006-0099-9

20. Sacks MM, Silk WK, Burman P. Effect of water stress on cortical cell division rates within the apical meristem of primary roots of maize. Plant Physiol. 1997;114:519-27. https://doi.org/10.1104/pp.114.2.519

21. Jaleel CA, Gopi R, Sankar B, Gomathinayagam M, Panneerselvam R. Differential responses in water use efficiency in two varieties of Catharanthus roseus under drought stress. Comp Rend Biol. 2008;331:42-47. https://doi.org/10.1016/j.crvi.2007.11.003 
22. Tahir MHN, Imran M, Hussain MK. Evaluation of sunflower (Helianthus annuus L.) inbred lines for drought tolerance. Int J Agric Biol. 2002;3:398-400. Available in: http://www.ijab.org

23. Wullschleger SD, Yin TM, DiFazio SP, Tschaplinski TJ, Gunter LE, Davis MF, et al. Phenotypic variation in growth and biomass distribution for two advancedgeneration pedigrees of hybrid poplar. Canadian J For Res. 2005;35:1779-89. https://doi.org/10.1139/x05-101

24. Mohammadian $\mathrm{R}$, Moghaddam $\mathrm{M}$, Rahimian $\mathrm{H}$, Sadeghian SY. Effect of early season drought stress on growth characteristics of sugar beet genotypes. Turk J Agric For. 2005;29(5):357-568. http://journals.tubitak.gov.tr/agriculture/abstract.htm? $\underline{\mathrm{id}=7880}$

25. Wu Y, Cosgrove DJ. Adaptation of roots to low water potentials by changes in cell wall extensibility and cell wall proteins. J Exp Bot. 2000;51:1543-53. https://doi.org/10.1093/jexbot/51.350.1543

26. Fahad S, Bajwa AA, Nazir U, Anjum SA, Farooq A, Zohaib A, et al. Crop production under drought and heat stress: plant responses and management options. Front Plant Sci. 2017;8:1147. https://doi.org/10.3389/fpls.2017.01147

27. Rucker KS, Kvien CK, Holbrook CC, Hook JE. Identification of peanut genotypes with improved drought avoidance traits. Peanut Sci. 1995;24:14-18. https://doi.org/10.3146/pnut.22.1.0003

28. Jaleel CA, Manivannan PA, Wahid A, Farooq M, AlJuburi HJ, Somasundaram RA, Panneerselvam R. Drought stress in plants: a review on morphological characteristics and pigments composition. Int J Agric Biol. 2009;11(1):100-05.

29. Khan MB, Hussain M, Raza A, Farooq S, Jabran K. Seed priming with $\mathrm{CaCl} 2$ and ridge planting for improved drought resistance in maize. Turk J Agric For. 2015;39:193-203. https://doi.org/10.3906/tar-1405-39 .

30. Nahar S, Kalita J, Sahoo L, Tanti B. Morpho physiological and molecular effects of drought stress in rice. Ann Plant Sci. 2016;5(09):1409-16.

31. Denčić S, Kastori R, Kobiljski B, Duggan B. Evaluation of grain yield and its components in wheat cultivars and landraces under near optimal and drought conditions. Euphytica. https://doi.org/10.1023/A:1003997700865

32. Zhang M, Duan L, Zhai Z, Li J, Tian X, Wang B, et al. Effects of plant growth regulators on water deficitinduced yield loss in soybean. In: Proceedings of the 4th international crop science congress, Brisbane, Australia: 2004. p. 252-56. Available in: http://www.regional.org.au/au/asa/2004/poster/1/3/4/57 $\underline{5 \text { zhangmc.htm }}$

33. Hsiao TC, O’Toole JC, Yambao EB, Turner NC. Influence of osmotic adjustment on leaf rolling and tissue death in rice (Oryza sativa L.). Plant Physiol. 1984;75:338-41. https://doi.org/10.1104/pp.75.2.338

34. Toole JC, Cruz RT, Singh TN. Leaf rolling and transpiration. Plant Sci Lett. 1979;16:111-14. https://doi.org/10.1016/0304-4211(79)90015-4

35. Hussain M, Malik MA, Farooq M, Ashraf MY, Cheema MA. Improving drought tolerance by exogenous application of glycinebetaine and salicylic acid in sunflower. J Agron Crop Sci. 2008;194:193-99. https://doi.org/10.1111/j.1439-037X.2008.00305.x
36. Kiliç H, Yağbasanlar T. The effect of drought stress on grain yield, yield components and some quality traits of durum wheat (Triticum turgidum ssp. durum) cultivars. Not Bot Hort Agrobot Cluj. 2010;38:164-70. https:// doi.org/10.15835/nbha3814274

37. Anjum SA, U Ashraf, M Tanveer, I Khan, S Hussain, B Shahzad, A Zohaib et al. Drought induced changes in growth, osmolyte accumulation and antioxidant metabolism of three maize hybrids. Front. Plant Sci. 2017; https://doi.org/10.3389/fpls.2017.00069

38. Kabay T, Erdinc C, Sensoy S. Effects of drought stress on plant growth parameters, membrane damage index and nutrient content in common bean genotypes. J Anim Plant Sci. 2007;27(3):940-52. Available in: http://www.thejaps.org.pk/.../31.pdf

39. Specht JE, Chase K, Macrander M, Graef GL, Chung J, Markwell JP, et al. Soybean response to water. Crop Sci. 2001;41(2):493-509. https://doi.org/doi:10.2135/cropsci2001.412493x

40. Wu QS, Xia RX, Zou YN. Improved soil structure and citrus growth after inoculation with three arbuscular mycorrhizal fungi under drought stress. Eur J Soil Biol. 2008;44:122-28.

https://doi.org/10.1016/j.ejsobi.2007.10.001

41. Bhatt RM, Srinivasa Rao NK. Influence of pod load response of okra to water stress. Indian J Plant Physiol. 2005;10:54-59. Available in: https://www.samviti.com/img/1341/society/publication/i jpp-10-1-009.pdf

42. Zhao TJ, Sun S, Liu Y, Liu JM, Liu Q, Yan YB, et al. Regulating the drought-responsive element (DRE)mediated signaling pathway by synergic functions of trans-active and transinactive DRE binding factors in Brassica napus. J Biol Chem. 2006;281:10752-59. Available http://www.jbc.org/content/283/10/6261.full

43. Kamara AY, Menkir A, Badu-Apraku B, Ibikunle O. The influence of drought stress on growth, yield and yield components of selected maize genotypes. J Agr Sci. 2003;141:43-50. https://doi.org/10.1017/S0021859603003423

44. Hussain HA, Men S, Hussain S, Chen Y, Ali S, Zhang S, Zhang K, Li Y, Xu Q, Liao C, Wang L. Interactive effects of drought and heat stresses on morpho-physiological attributes, yield, nutrient uptake and oxidative status in maize hybrids. Sci. Rep. 2019; 9:3890. https://doi.org/ 10.1038/s41598-019-40362-7

45. Nayyar H, Kaur S, Singh S, Upadhyaya HD. Differential sensitivity of Desi (small-seeded) and Kabuli (largeseeded) chickpea genotypes to water stress during seed filling: effects on accumulation of seed reserves and yield. J Sci Food Agr. 2006;86:2076-2082. https://doi.org 10.1002/jsfa.2574

46. Petropoulos SA, Daferera D, Polissiou MG, Passam HC. The effect of water deficit stress on the growth, yield and composition of essential oils of parsley. Sci Hortic. 2008;115(4):393-97. https://doi.org/10.1016/j.scienta.2007.10.008

47. Alghabari F, Ihsan MZ, Hussain S, Aishia G, Daur I. Effect of Rht alleles on wheat grain yield and quality under high temperature and drought stress during booting and anthesis. Environ. Sci. Pollut. Res. 2015; 20:15506-15 https://doi.org/10.1007/s11356-015-4724-z

48. Anjum SA, Tanveer M, Hussain S, Tung SA, Samad RA, Wang L. Exogenously applied methyl jasmonate improves the drought tolerance in wheat imposed at early and late developmental stages. Acta Physiol. 
Plant. 2016;38: 1-11. https://doi.org/10.1007/s11738-015$\underline{2047-9}$

49. Edward D, Wright D. The effects of winter waterlogging and summer drought on the growth and yield of winter wheat (Triticum aestivum L.). Eur J Agron. 2008;28:234-44. https://doi.org/10.1016/j.eja.2007.07.010

50. Estrada-Campuzano G, Miralles DJ, Slafer GA. Genotypic variability and response to water stress of pre- and post-anthesis phases in triticale. Eur J Agron. 2008;28:171-77. https://doi.org/10.1016/j.eja.2007.07.005

51. Cattivelli L, Rizza F, Badeck FW, Mazzucotelli E, Mastrangelo AM, Francia E, et al. Drought tolerance improvement in crop plants: An integrative view from breeding to genomics. Field Crop Res. 2008;105:1-14. https://doi.org/10.1016/j.fcr.2007.07.004

52. Wardlaw IF, Willenbrink J. Mobilization of fructan reserves and changes in enzyme activities in wheat stems correlate with water stress during kernel filling. New Phytol. 2000;148:413-22. https://doi.org/10.1046/j.1469-8137.2000.00777.x

53. Taiz L, Zeiger E. Plant Physiology, 4th ed. Sinauer Associates Inc. Publishers, Massachusetts: 2006.

54. Ahmadi A, Baker DA. The effect of water stress on the activities of key regulatory enzymes of the sucrose to starch pathway in wheat. Plant Growth Regul. 2001;35:81-91.

https://doi.org/10.1023/A:1013827600528

55. Rizza F, Badeck FW, Cattivelli L, Lidestri O, Di Fonzo N, Stanca AM. Use of a water stress index to identify barley genotypes adapted to rainfed and irrigated conditions. Crop Sci. 2004;44(6):2127-37. https://doi.org/ 10.2135/cropsci2004.2127

56. Samarah NH. Effects of drought stress on growth and yield of barley. Agron Sustain Dev. 2005;25:145-49. Available in: ouvertes.fr/hal-00886257/

https://hal.archives-

57. Lafitte HR, Yongsheng G, Yan S, Li1 ZK. Whole plant responses, key processes, and adaptation to drought stress: the case of rice. J Exp Bot. 2007;58:169-75. https:// doi.org/10.1093/jxb/erl101

58. Sinaki JM, Heravan EM, Rad AHS, Noormohammadi G, Zarei G. The effects of water deficit during growth stages of canola (Brassica napus L.). Am Euras J Agri Environ Sci. 2007;2:417-422.

59. Samarah NH, Mullen RE, Cianzio SR, Scott P. Dehydrinlike proteins in soybean seeds in response to drought stress during seed filling. Crop Sci. 2006;46;2141-50. https://doi.org/10.2135/cropsci2006.02.0066

60. Nam NH, Chauhan YS, Johansen C. Effect of timing of drought stress on growth and grain yield of extra-shortduration pigeonpea lines. J Agr Sci. 2001;136:179-89. https://doi.org/10.1017/S0021859601008607

61. Ogbonnaya CI, Sarr B, Brou C, Diouf O, Diop NN, RoyMacauley $H$. Selection of cowpea genotypes in hydroponics, pots, and field for drought tolerance. Crop Sci. 2003;43:1114-20 https://doi.org/10.2135/cropsci2003.1114

62. Mazahery-Laghab H, Nouri F, Abianeh HZ. Effects of the reduction of drought stress using supplementary irrigation for sunflower (Helianthus annuus) in dry farming conditions, Pajouheshva- Sazandegi. Agron Hort. 2003;59:81-86. Available in http://agris.fao.org/agris-search/search.do? recordID=IR2011005006
63. Manivannan P, Jaleel CA, Sankar B, Kishorekumar A, Somasundaram R, Lakshmanan GA, Panneerselvam R. Growth, biochemical modifications and proline metabolism in Helianthus annuus L. as induced by drought stress. Colloids and Surfaces B: Biointerfaces. 2007;59(2):141-49.

https://doi.org/10.1016/j.colsurfb.2007.05.002

64. Guerfel M, Baccouri O, Boujnah D, Chaibi W, Zarrouk M. Impacts of water stress on gas exchange, water relations, chlorophyll content and leaf structure in the two main Tunisian olive (Olea europaea L.) cultivars. Sci Horticult. 2009;119:257-63. https://doi.org/10.1016/j.scienta.2008.08.006

65. Ghannoum, O. C4 photosynthesis and water stress. Ann Bot. 2008;103(4):635-44. https://doi.org/10.1093/aob/mcn093

66. Jaleel CA, Manivannan P, Kishorekumar A, Sankar B, Gopi R, Somasundaram R, et al. Alterations in osmoregulation, antioxidant enzymes and indole alkaloid levels in Catharanthus roseus exposed to water deficit. Colloids and Surfaces B: Biointerfaces. 2007;59(2):150-57. https://doi.org/10.1016/j.colsurfb.2007.05.001

67. Prochazkova D, Sairam RK, Srivastava GC, Singh DV. Oxidative stress and antioxidant activity as the basis of senescence in maize leaves. Plant Sci. 2001;161:765-71. https://doi.org/10.1016/S0168-9452(01)00462-9

68. Havaux M. Carotenoids as membrane stabilizers in chloroplasts. Trends Plant Sci. 1998;3:147-151. https://doi.org/10.1016/S1360-1385(98)01200-X

69. Anjum SA, Tanveer M, Hussain S, Ashraf U, Khan I, Wang L. Alteration in growth, leaf gas exchange, and photosynthetic pigments of maize plants under combined cadmium and arsenic stress. Water Air Soil Pollut. 2017; 228:13 https://doi.org/10.1007/s11270-016-3187-2

70. Saud S, Li X, Chen Y, Zhang L, Fahad S, Hussain S, Sadiq A, Chen Y. Silicon application increases drought tolerance of Kentucky bluegrass by improving plant water relations and morphophysiological functions. Sci. World J. 2014; https://doi.org/10.1155/2014/368694

71. Brown KW, Thomas JC. The influence of water stress preconditioning on dark respiration. Physiol Plantarum. 1980;49:205-09. https://doi.org/10.1111/j.1399-3054.1980.tb02653.x

72. Boyer JS. Leaf enlargement and metabolic rates in corn, soybean, and sunflower at various leaf water potentials. Plant Physiol. 1970;46:233-35. https://doi.org/ 10.1104/pp.46.2.233

73. Rice JR, Eastin JD. Grain sorghum root response to water and temperature during reproductive development. Crop Sci. 1986;26:547-51. https://doi.org/10.2135/cropsci1986.0011183X002600030 $\underline{025 x}$

74. Pheloung P, Barlow EWR. Respiration and carbohydrates accumulation in the water stressed wheat apex. J Exp Bot. 1981;32:921-31.

75. McCree KJ. Measuring of whole plant daily carbon balance. Photosynthetica. 1986;20:82-93. Available in http://agris.fao.org/agris-search/search.do? recordID=US201301414480

76. Penning de Vries FWT, Witlage J, Kremer D. Rates of respiration and of increase in structural dry matter in young wheat, rye grass and maize plants in relation to temperature, to water stress and to their sugar content. Ann Bot. 1979;44:595-609. https://doi.org/10.1093/oxfordjournals.aob.a085772 
77. Wilson DR, Van Bavel CHM, McCree KJ. Carbon balance of water deficit grain sorghum plants. Crop Sci. 1980;20:153-59.

https://doi.org/10.2135/cropsci1980.0011183X002000020 $\underline{001 x}$

78. Lawlor DW. Water stress induced changes in photosynthesis, photorespiration, respiration, $\mathrm{Co} 2$ compensation concentration of wheat. Photosynthetica. 1976;10:378-87. Available http://agris.fao.org/agris-search/search.do? recordID=US201301254780

79. Upchurch RP, Peterson ML, Hagan RM. Effect of soil moisture content on the rate of photosynthesis and respiration in the ladino clover (Trifolium repens L.). Plant Physiol. 1995;30:297-303. Available in: https://www.ncbi.nlm.nih.gov/pmc/articles/PMC540651/

80. Shearman LL, Esatin JD, Sullivan CY, Kinbacher EJ. Carbon dioxide exchange in water stressed maize sorghum. Crop Sci. 1972;12:406-09. https://doi.org/10.2135/cropsci1972.0011183X001200040 $002 x$

81. Collier DE, Cummins WR. The rate of development of water deficits affects Saxifraga cernua leaf respiration. Physiol Plantarum. 1996;96:291-97. https://doi.org/10.1111/j.1399-3054.1996.tb00216.x

82. Egilla JN, Davies FT, Boutton TW. Drought stress influences leaf water content, photosynthesis, and water-use efficiency of Hibiscus rosa-sinensis at three potassium concentrations. Photosynthetica. 2005;43(1):135-40. $\quad$ https://doi.org/10.1007/s11099-005$\underline{5140-2}$

83. Bilal M, Rashid RM, Rehman SU, Iqbal F, Ahmed J, Abid MA, et al. Evaluation of wheat genotypes for drought tolerance. J Green Physiol Genet Genomics. 2015;1:1121.

84. Dhanda S, Sethi G, Behl R. Indices of drought tolerance in wheat genotypes at early stages of plant growth. J Agron Crop Sci. 2004;190:6-12. https://doi.org/10.1111/j.1439-037X.2004.00592.X

85. Farshadfar E, Farshadfar M, Moradi F. Screening Agronomic, Physiological and Metabolite Indicators of Drought Tolerance in Bread Wheat (Triticum aestivum L). Am J Sci Res. 2011;38:88-96. Available in: http://www.globalsciencebooks.info/Online/GSBOnline/i mages/2011/IJPB 5(1)/IJPB 5(1)42-47o.pdf

86. Sairam RK, Saxena DC. Oxidative stress and antioxidant in wheat genotypes: possible mechanism of water stress tolerance. J Agron Crop Sci. 2000;184:55-61. https://doi.org/10.1046/j.1439-037x.2000.00358.x

87. Aziz O, Hussain S, Rizwan M, Riaz M, Bashir S, Lin L, Mehmood S, Imran M, Yaseen R, Lu G. Increasing water productivity, nitrogen economy, and grain yield of rice by water saving irrigation and fertilizer-N management. Environ. Sci. Pollut. Res. 2018; 1-5. https://doi.org/10.1007/s11356-018-1855-z

88. Siddique MRB, Hamid A, Islam MS. Drought stress effects on water relations of wheat. Bot Bull Acad Sin. 2001;41:35-39. Available in: https://ejournal.sinica.edu.tw/bbas/content/2000/1/bot1 1-06.html

89. Nayyar H, Gupta D. Differential sensitivity of C3 and C4 plants to water deficit stress: association with oxidative stress and antioxidants. Environ Exp Bot. 2006;58:10613. https://doi.org/10.1016/j.envexpbot.2005.06.021

90. Nerd A, Nobel PS. Effects of drought on water relations and nonstructural carbohydrates in cladodes of
Opuntia ficus-indica. Physiol Plant. 1991;81:495-500. https://doi.org/10.1111/j.1399-3054.1991.tb05090.x

91. Abbate PE, Dardanellib JL, Cantareroc MG, Maturanoc M, Melchiorid RJM, Sueroa EE. Climatic and water availability effects on water-use efficiency in wheat. Crop Sci. 2004;44:474-83. https://doi.org/10.2135/cropsci2004.4740

92. Roohi E, Tahmasebi-Sarvestani Z, Modarres-Sanavy SAM, Siosemardeh A. Comparative Study on the effect of soil water stress on photosynthetic function of triticale, bread wheat, and barley. J Agr Sci Tech. 2003;15:215-28. Available in: http://hehp.modares.ac.ir/article-23-10280-en.pdf

93. Purwanto E. Photosynthesis activity of soybean (Glycine $\max$ L.) under drought stress. Agrosains J. 2003;5(1):13-18.

94. Levitt. Responses of plants to environmental stresses. Physiological Ecology Series. Academic, Michigan. 1980. Available in https://www.cabdirect.org/cabdirect/abstract/19802605 739

95. Turner NC. Drought resistance: a comparison of two research frameworks. In: Saxena NP editor. Management of Agricultural Drought: Agronomic and Genetic Options. Science Publishers, Inc: 2003. p. 89102.

96. Bhatia VS, Jumrani K, Pandey GP. Developing drought tolerance in soybean using physiological approaches. Soybean Res. 2014;12:1-19. Available in: http://soybeanresearch.in/pdf/2014-Issue1.pdf

97. Blum A. Breeding methods for drought resistance plants under stress In: Jones H. G, Flowers TJ, Jones MB editors. Biochemistry, Physiology and Ecology and their Application to Plant Improvement. Cambridge University Press, Cambridge: 1989. p. 197-215.

98. Boyer SJ. Advances in drought tolerance in plants. Adv Agron. 1996;56:187-218.

99. Barnabas B, Jager K, Feher A. The effect of drought and heat stress on reproductive processes in cereals. Plant Cell Env. 2008;31:11-38. https://doi.org/10.1111/j.1365-3040.2007.01727.x

100. Bodner G, Nakhforoosh A, Kaul HP. Management of crop water under drought: a review. Agron Sustain Dev. 2015;35:401-42 https://doi.org/10.1007/s13593-015-0283-4

101. Kramer PJ. Drought, stress, and the origin of adaptations. In: Turner NC, Kramer PJ editors. Adaptations of Plants to Water and High Temperature Stress. John-Wiley \& Sons, New York: 1980. p. 7-20. Available in: https://www.cabdirect.org/cabdirect/abstract/19810718581

102. Morgan PW. Effects of abiotic stresses on plant hormone systems, in: Stress Responses in plants: adaptation and acclimation mechanisms. Wiley-Liss, Inc. 1990. p. 113-46.

103. Turner NC, Wright GC, Siddique KHM. Adaptation of grain legumes (pulses) to water-limited environments. Adv Agron. 2001;71:123-31. https://doi.org/10.1016/S0065-2113(01)71015-2

104. Ashraf M, Bokhari MH, Chishti SN. Variation in osmotic adjustment of accessions of lentil lens culinaris medic. In response to drought stress. Acta Bot Neerl. 1992;41:51-62. https://doi.org/10.1111/j.14388677.1992.tb01310.x 
105. Hudak CM, Patterson RP. Root distribution and soil moisture depletion of a drought resistant soybean plant introduction. Agron J. 1996;88:478-485. https://doi.org/10.2134/agronj1996.00021962008800030020x

106. Sponchiado BN, White JW, Castillo JA, Jones PG. Root growth of four common bean cultivars in relation to drought tolerance in environments with contrasting soil types. Exp Agr. 1989;25:249-57. https://doi.org/10.1017/S0014479700016756

107. Rhodes D, Samaras Y. Genetic control of osmoregulation in plants. In: Strange, K. Boca Raton editors. Cellular and molecular physiology of cell volume regulation, CRC Press: 1994. p. 347-61.

108. Demiral T, Turkan I. Does exogenous glycinebetaine affect antioxidative system of rice seedlings under $\mathrm{NaCl}$ treatment? J Plant Physiol. 2004;161:1089-1110. https://doi.org/10.1016/j.jplph.2004.03.009

109. Hussain S, Khan F, Hussain HA, Nie L. Physiological and biochemical mechanisms of seed priming-induced chilling tolerance in rice cultivars. Front. Plant Sci. 2016; https://doi.org/10.3389/fpls.2016.00116

110. Szabo L, Savoure A. Proline: a multifunctional amino acid. Trends Plant Sci. 2010;15(2):89-97. https://doi.org/10.1016/j.tplants.2009.11.009

111. Nayyar H, Walia DP. Water stress induced proline accumulation in contrasting wheat genotypes as affected by calcium and abscisic acid. Biol Plant. 2003;46:275-79.

https://doi.org/10.1023/A:1022867030790

112. Fukai S, Sittisuang P, Chanphengsay M. Increasing production of rain fed low land rice in drought prone environments: a case study in Thailand and Laos. Plant Prod Sci. 1998;1:75-82. https://doi.org/10.1626/pps.1.75

113.El Nadi AH. The significance of leaf area in evapotranspiration. Ann Bot. 1974;38:607-611. https://doi.org/10.1093/oxfordjournals.aob.a084846

114. Korres NE, Norsworthy JK, Tehranchian P, Gitsopoulos TK, Loka DA, Oosterhuis DM, et al. Cultivars to face climate change effects on crops and weeds: a review. Agron Sustain Dev. 2016;36(1):12. https://doi.org/10.1007/s13593-016-0350-5

115. Sekhon HS, Singh G, Sharma P, Bains TS. Water use efficiency under stress environments. In: Climate change and management of cool season grain legume crops. Springer Netherlands: 2010. p. 207-27.

116. Mahmood A, Ihsan MZ, Khaliq A, Hussain S, Cheema ZA, Naeem M, Daur I, Alghabari F. Crop residues mulch as organic weed management strategy in maize. Clean Soil Air Water 2016; 4:317-24 https://doi.org/10.1002/clen.201500155

117. Jensen CR. Some options for securing water resources for agricultural production. In Cracow-Plant-Stress Conference. 2013. p. 9-25.

118. Lipiec J, Doussan C, Nosalewicz A, Kondracka K. Effect of drought and heat stresses on plant growth and yield: a review. Int Agrophys. 2013;27(4):463-77. https://doi.org/10.2478/intag-2013-0017

119. Hussain S, Zheng M, Peng S, Fahad S, Khaliq A, Huang J, Cui K, Nie L. Benefits of rice seed priming are offset permanently by prolonged storage and the storage conditions. $\quad$ Sci. $\quad$ Rep. 2015; https://doi.org/10.1038/srep08101

120. Du LV, Tuong TP. Enhancing the performance of dryseeded rice: effects of seed priming, seedling rate, and time of seedling. Direct seeding: research strategies and opportunities. 2002. p. 241-56.

121. Ajouri A, Asgedom H, Becker M. Seed priming enhances germination and seedling growth of barley under conditions of $\mathrm{P}$ and Zn deficiency. J Plant Nutr Soil Sci. 2004;167(5):630-36.

https://doi.org/10.1002/jpln.200420425

122. Das JC, Choudhury AK. Effect of seed hardening, potassium fertilizer, and paraquat as anti-transpirant on rainfed wheat (Triticum aestivum L.). Indian J Agron. 1996;41:397-400.

123. Ghana SG, Schillinger WF. Seed priming winter wheat for germination, emergence, and yield. Crop Sci. 2003;43:2135-41. https://doi.org/10.2135/cropsci2003.2135

124. Akbari G, Sanavy SA, Yousefzadeh S. Effect of auxin and salt stress $(\mathrm{NaCl})$ on seed germination of wheat cultivars (Triticum aestivum L.). Pak J Biol Sci. 2007;10:2557-61. Available in https://scialert.net/fulltextmobile/?doi=pjbs.2007.2557.2561

125. Wahid A, Perveen M, Gelani S, Shahzad MA, Basra SMA. Pretreatment of seed with $\mathrm{H} 2 \mathrm{O} 2$ improves salt tolerance of wheat seedlings by alleviation of oxidative damage and expression of stress proteins. J Plant Physiol. https://doi.org/10.1016/j.jplph.2006.01.005

126. Basra SMA, Farooq M, Tabassum R. Physiological and biochemical aspects of seed vigour enhancement treatments in fine rice (Oryza sativa L.). Seed Sci Technol. 2005;33:623-28 https://doi.org/10.15258/sst.2005.33.3.09

127. Faroog M, Basra SMA, Wahid A, Ahamad N. Changes in nutrient homeostasis and reserve metabolism during rice seed priming: consequences for seedling emergence and growth. Agric Sci China. 2010;9:191-98. https://doi.org/10.1016/S1671-2927(09)60083-3

128. Yari L, Sheidaie S. Effect of seed priming on seed germination's behavior of rice (Oryza sativa L.). Int J Agric Sci. 2011;1:45-51. Available in: https://www.cabdirect.org/cabdirect/abstract/20123239761

129. Yuan-Yuan S, Yong-Jian S, Ming-Tian W, Xu-Yi LI, Xiang GUO, Rong HU, et al. Effects of seed priming on germination and seedling growth under water stress in rice. Acta Agron Sin. 2010;36:1931-40. https://doi.org/10.1016/S1875-2780(09)60085-7

130. Murungu FS, Nyamugafata P, Chiduza C, Clark LJ, Whalley WR. Effects of seed priming, aggregate size and soil matric potential on emergence of cotton (Gossypium hirsutum L.) and maize (Zea mays L.). Soil Tillage Res. 2003;74:161-68. https://doi.org/10.1016/j.still.2003.06.003

131. Finch-Savage WE, Dent KC, Clark LJ. Soak conditions and temperature following sowing influence the response of maize (Zea mays L.) seeds to on-farm priming (pre-sowing seed soak). Field Crops Res. 2004;90:361-74. https://doi.org/10.1016/j.fcr.2004.04.006

132. Foti R, Aburenia K, Tigerea A, Gotosab J, Gerec J. The efficacy of different seed priming osmotica on the establishment of maize (Zea mays L.) caryopses. J Arid Environ. https://doi.org/10.1016/j.jaridenv.2007.11.008

133. Janmohammadi M, Moradi Dezfuli P, Sharifzadeh F. Seed invigoration techniques to improve germination and early growth of inbred line of maize under salinity and drought stress. Gen Appl Plant Physiol. 2008;34:215-26. Available in 
http://citeseerx.ist.psu.edu/viewdoc/summary? $\underline{\mathrm{doi}=10.1 \cdot 1.399 .1176}$

134. Patade VY, Sujata B, Suprasanna P. Halopriming imparts tolerance to salt and PEG induced drought stress in sugarcane. Agric Ecosyst Environ. 2009;134:2428. https://doi.org/10.1016/j.agee.2009.07.003

135. Casenave EC, Toselli ME. Hydropriming as a pretreatment for cotton germination under thermal and water stress conditions. Seed Sci Technol. 2007;35:8898. $\quad$ https://doi.org/10.15258/sst.2007.35.1.08

136. Kaur S, Gupta AK, Kaur N. Effect of osmo- and hydropriming of chickpea on seedling growth and carbohydrate metabolism under water deficit stress. Plant Growth Regul. 2002;37:17-22. https://doi.org/10.1023/A:1020310008830

137. Kaur S, Gupta AK, Kaur N. Seed priming increases crop yield possibly by modulating enzymes of sucrose metabolism in chickpea. J Agron Crop Sci. 2005;19:8187. https://doi.org/10.1111/j.1439-037X.2004.00140.x

138. Elkoca E, Haliloglu K, Esitken A, Ercisli S. Hydro- and osmopriming improve chickpea germination. Acta Agric Scand Sect B Soil Plant Sci. 2007;57:193-200. https://doi.org/10.1080/09064710600914087

139. Srivastava AK, Lokhande VH, Patade VY, Suprasanna P, Sjahril R, D'Souza SF. Comparative evaluation of hydro-, chemo-, and hormonal priming methods for imparting salt and PEG stress tolerance in Indian mustard (Brassica juncea L.). Acta Physiol Plant. 2010;32:1135-44. $\quad$ https://doi.org/10.1007/s11738-0100505-y

140. Srivastava AK, Suprasanna P, Srivastava S, D’Souza SF. Thiourea mediated regulation in the expression profile of aquaporins and its impact on water homeostasis under salinity stress in Brassica juncea roots. Plant Sci. 2010;178:517-22.

https://doi.org/10.1016/j.plantsci.2010.02.015

141. Omidi H, Khazaei F, Hamzi Alvanagh S, HeidariSharifabad H. Improvement of seed germination traits in canola (Brassica napus L.) as affected by saline and drought stresses. Plant Ecol Physiol. 2009;3:151-58. Available http://thaiscience.info/Journals/Article/IJAT/10842423.pdf

142. Nonami H. Plant water relations and control of cell elongation at low water potentials. J Plant Res. 1998;111:373-82. https://doi.org/10.1007/BF02507801

143. Anjum F, Yaseen M, Rasul E, Wahid A, Anjum S. Water stress in barley (Hordeum vulgare L.). II. Effect on chemical composition and chlorophyll contents. Pak J Agric Sci. 2003;40:45-49. Available in: https://www.pakjas.com.pk/papers/536.pdf

144. Foyer CH, Noctor G. Oxygen processing in photosynthesis: regulation and signaling. New Phytologist. 2000;146:359-88.

145. Efeoğlu B, Ekmekci Y, Cicek N. Physiological responses of three maize cultivars to drought stress and recovery. S Afr J Bot. 2009;75(1):34-42. https://doi.org/10.1016/j.sajb.2008.06.005

146. Guo YY, Yu HY, Kong DS, Yan F, Zhang YJ. Effects of drought stress on growth and chlorophyll fluorescence of Lycium ruthenicum Murr. seedlings. Photosynthetica. 2016;54(4):524-31.

https://doi.org/10.1007/s11099-016-0206-x

147. Hussain S, Khaliq A, Tanveer M, Matloob A, Hussain HA. Aspirin priming circumvents the salinity-induced effects on wheat emergence and seedling growth by regulating starch metabolism and antioxidant enzyme activities. Acta Physiol. Plant. 2018; 40:68 https://doi.org/10.1007/s11738-018-2644-5.

148. Kiran S. Effects of Vermicompost on Some Morphological, Physiological and Biochemical Parameters of Lettuce (Lactuca sativa var. crispa) under Drought Stress. Not Bot Horti Agrobo. 2019;47(2):352-58. https://doi.org/10.15835/nbha47111260

149. Kavar T, Maras M, Kidric M, Sustar-Vozlic J, Meglic V. Identification of genes involved in the response of leaves of Phaseolus vulgaris to drought stress. Mol Breed. https://doi.org/10.1007/s11032-007-9116-8

150. Maurel C, Chrispeels MJ. Aquaporins: a molecular entry into plant water relations. Plant Physiol. 2001;125:135138. https://doi.org/10.1104/pp.125.1.135

151. Javot H, Maurel C. The role of aquaporins in root water uptake. Ann Bot. 2002;90:301-13. https://doi.org/10.1093/aob/mcf199

152. Javot H, Lauvergeat V, Santoni V, Martin-Laurent F, Guclu J, Vinh J, et al. Role of a single aquaporin isoform in root water uptake. Plant Cell. 2003;15:509-522. https://doi.org/10.1105/tpc.008888

153. Aharon R, Shahak Y, Wininger S, Bendov R, Kapulnik Y, Galili G. Overexpression of a plasma membrane aquaporins in transgenic tobacco improves plant vigour under favourable growth conditions but not under drought or salt stress. Plant Cell. 2003;15:439-47. https://doi.org/10.1105/tpc.00922

154. Wahid A, Gelani S, Ashraf M, Foolad MR. Heat tolerance in plants: an overview. Environ Exp Bot. 2007;61:199-23.

https://doi.org/10.1016/j.envexpbot.2007.05.011

155. Choi DW, Rodriguez EM, Close TJ. Barley Cbf3 Gene identification, expression pattern, and map location. Plant Physiol. 2002;129:1781-87. https://doi.org/10.1104/ pp.003046

156. Agarwal PK, Agarwal P, Reddy MK, Sopory SK. Role of DREB transcription factors in abiotic and biotic stress tolerance in plants. Plant Cell Rep. 2006;25:1263-74. https://doi.org/10.1007/s00299-006-0204-8

157. Mathur PB, Devi MJ, Serraj R, Yamaguchi-Shinozaki K, Vadez V, Sharma KK. Evaluation of transgenic groundnut lines under water limited conditions. Int Archis Newslett. 2004;24:33-34. Available in: http://oar.icrisat.org/id/eprint/3274

158. Yamaguchi-Shinozaki K, Shinozaki K. Improving drought and cold stress tolerance in transgenic rice. Proceedings of World Rice Research Conference, Tsukuba, Japan, 5-7 November 2004

159. Huang B, Liu JY. Cloning and functional analysis of the novel gene GhDBP3 encoding a DRE-binding transcription factor from Gossypium hirsutum. Biochim Biophys Acta. 2006;1759:263-69. https://doi.org/10.1016/j.bbaexp.2006.04.006

160.Zhao J, Ren W, Zhi D, Wang L, Xia G. Arabidopsis DREB1A/CBF3 bestowed transgenic tall fescue increased tolerance to drought stress. Plant Cell Rep. 2007;26:1521-1528.

161. Mahajan S, Tuteja N. Cold, salinity and drought stresses: an overview. Arch Biochem Biophys. 2005;444:139-58. $\quad$ https://doi.org/10.1007/s00299-007$\underline{0362-3}$

162. Hussain S, Yin H, Peng S, Khan FA, Khan F, Huang J, Cui $\mathrm{K}$, Nie L. Comparative transcriptional profiling of 
primed and non-primed rice seedlings under submergence stress. Front. Plant Sci. 2016; https://doi.org/10.3389/fpls.2016.01125

163. Gorantla M, Babu PR, Lachagari VBR, Reddy AMM, Wusirika R, Bennetzen JL, et al. Identification of stressresponsive genes in an indica rice (Oryza sativa L.) using ESTs generated from drought-stressed seedlings. J Exp Bot. 2006;58:253-265. https://doi.org/10.1093/jxb/erl213

164. Khaliq A, Aslam F, Matloob A, Hussain S, Wahid A, Rehman H. Seed priming with selenium: consequences for emergence, seedling growth and biochemical attributes of rice. Biol. Trace Element Res. 2015; 166:236-44 https://doi.org/10.1007/s12011-015-0260-4

165. Zheng M, Tao Y, Hussain S, Jiang Q, Peng S, Huang J, et al. Seed priming in dry direct-seeded rice: consequences for emergence, seedling growth and associated metabolic events under drought stress. Plant Growth Regul. 2016;78(2):167-78. doi.org/10.1007/s10725-015-0083-5 